\title{
Tussen kunst en wetenschap
}

Citation for published version (APA):

Bosman, F. T. (1983). Tussen kunst en wetenschap. Maastricht University. https://doi.org/10.26481/spe.19830225fb

Document status and date:

Published: 25/02/1983

DOI:

10.26481/spe.19830225fb

Document Version:

Publisher's PDF, also known as Version of record

\section{Please check the document version of this publication:}

- A submitted manuscript is the version of the article upon submission and before peer-review. There can be important differences between the submitted version and the official published version of record.

People interested in the research are advised to contact the author for the final version of the publication, or visit the DOI to the publisher's website.

- The final author version and the galley proof are versions of the publication after peer review.

- The final published version features the final layout of the paper including the volume, issue and page numbers.

Link to publication

\footnotetext{
General rights rights.

- You may freely distribute the URL identifying the publication in the public portal. please follow below link for the End User Agreement:

www.umlib.nl/taverne-license

Take down policy

If you believe that this document breaches copyright please contact us at:

repository@maastrichtuniversity.nl

providing details and we will investigate your claim.
}

Copyright and moral rights for the publications made accessible in the public portal are retained by the authors and/or other copyright owners and it is a condition of accessing publications that users recognise and abide by the legal requirements associated with these

- Users may download and print one copy of any publication from the public portal for the purpose of private study or research.

- You may not further distribute the material or use it for any profit-making activity or commercial gain

If the publication is distributed under the terms of Article $25 \mathrm{fa}$ of the Dutch Copyright Act, indicated by the "Taverne" license above, 


\section{TUSSEN KUNST EN WETENSCHAP}

Rede uitgesproken bij de aanvaarding van het ambt van gewoon hoogleraar in de pathologie aan de Rijksuniversiteit Limburg op vrijdag 25 februari 1983

Dr. F.T. Bosman 



\section{TUSSEN KUNST EN WETENSCHAP}

Rede uitgesproken bij de aanvaarding van het ambt van gewoon hoogleraar in de pathologie aan de Rijksuniversiteit Limburg op vrijdag 25 februari 1983

Dr. F.T. Bosman 

Door wijsheid wordt een huis gebouwd, door verstand wordt het bevestigd; door kennis worden de kamers gevuld, met allerlei kostbaar en lieflijk bezit.

Spreuken 24: 3,4. 
Mijnheer de Rector Magnificus,

Dames en Heren Leden van het Universiteitsbestuur,

Dames en Heren Leden van de Universiteitsraad,

Dames en Heren Hoogleraren, Docenten en Leden van de Wetenschappelijke Staf,

Dames en Heren. Leden van de Technische en Administratieve Staf,

Dames en Heren Studenten

en voorts gij allen die deze plechtigheid vereert met Uw aanwezigheid,

Zeer gewaardeerde toehoorders,

Als men aan willekeurige Nederlanders de vraag zou stellen wat Pathologie is, zou vermoedelijk blijken dat de inhoud van dat begrip goeddeels onbekend is. Een aanzienlijk deel van de ondervraagden zou meteen denken aan een bekend Nederlander, die al zeer lang een uiterst persoonlijk stempel drukt op de gerechtelijke geneeskunde in ons land. Een aantal ondervraagden zou wellicht aarzelend de naam van Quincy laten vallen, die in de gelijknamige Amerikaanse t.v.-serie, met een zelfs voor een patholoog opmerkelijke inventiviteit, de meest ingewikkelde gerechtelijk-geneeskundige problematiek tot een doorgaans spectaculaire oplossing wist te brengen. Een enkeling zal wellicht de naam noemen van David Coleman, de jonge patholoog van wiens professionele perikelen een opmerkelijk realistisch beeld wordt geschetst in de roman "The final diagnosis" van Arthur Hailey. Alleen degenen die een patholoog anatoom zelf kennen of mett diens werk door een persoonlijke ervaring met ziekte zijn geconfronteerd, zullen een redelijk beeld hebben van de rol die deze medisch specialist speelt in de moderne gezondheidszorg.

Mijn zoon, met zijn tien jaar door de verhalen van zijn vader kennelijk al redelijk geïnformeerd, gaf het volgende antwoord: "Een dokter haalt iets uit iemands buik. Dan komt hij naar mijn vader toe en vraagt: Wilt $U$ even kijken of dit wel ziek is? Dan doet mijn vader het onder de microscoop en dan zegt hij of het ziek is". 
In al deze reacties op de vraag wat pathologie is, staat de rol van de patholoog-anatoom centraal; kennelijk bestaat de indruk dat palhologie en pathologische anatomie congruent zijn. Dat is een wild verbreid misverstand en daarom wil ik $U$ in de eerste plaats de betekenis van de pathologie in de ontwikkeling wan de geneeskumst schetsen. Aangezien ik zelf patholoog-anatoom ben en mijn bezig zijn met pathologie voor een aanzienlijk deel door dat uttgangspunt wordt bepaald. wil ik vervolgens een aantal ontwikkelingen in dat medisch specialisme schetsen. Tenslotte wil ik met $U$ bespreken welke rol pathologie in het onderwijs aan studenten in de geneeskunde kan spelen. I $\mathrm{k}$ heb als motto voor deze bespiegelingen "tussen kunst en wetenschap" gekazen. Met kunst is hier geneeskunst bedoeld, te definieren als de toepassing van de kennis van de gesteldheid en de oorzaken der ongesteldheden van het menselijk lichaam en van de middelen om die te genezen. Met wetenschap is hier biomedische basiswetenschap bedoeld, te definieren als het systematisch geordende geheel van het weten en van de regels waarmee verdere kennis verkregen kan worden, voor zover betrekking hebbend op bouw en functie van het menselijke lichaam.

\section{Pathologie: schakel inssen geneeskunst en biomedische basiswerenschap}

Geneeskunst is ouder dan de weg naar Rome. Ongetwijfeld hebben sedert het ontstaan der mensheid enkelingen meer dan gemiddelde belangstelling gehad voor het verschijnsel ziekte en zich bekwaamd in de behandeling ervan. De primitieve mens ontdekte door "trial and error" dat sommige planten geneeskrachtig waren en verkreeg daarmee voor alledaagse kwalen een remedie. Waarschijnijk werden dergelijke ongemakken aanvaard als natuurlijk onderdeel van het bestaan. Emstige. misvormende of dodelijke aandoeningen werden echter beschouwd als bovennatuurlijk, gevolg van de invloed van een kwade demon of onwelgevallige god. Bovennatuurlijke verschijnselen werden niet met natuurlijke middelen bestreden: daarvoor waren magische of religieuze handelingen noodzakelijk die dan ook in de primitieve geneeskunst een belangrijke rol speelden.

De overgang van magie naar wetenschap is een langdurig en zeer geleidelijk proces geweest, waaraan in de vroege geschiedenis, 
India is bilgedragen. Vroeg in de Griekse geschiedenis brak het besef door dat ziekte niet of niet alleen hef gevolg kon zijn van bovennatuurlijke invloeden. In de vijfde eeuw voor Christus ontwikkelde Empedocles de gedachte dat het universum is opgebouwd uit de vier elementen vuur, water, aarde en lucht. Dit denkbeeld vormde de grondslag voor de doctrine van de vier lichaamsvioeistoffen: bloed, slijm, gele gal en zwarte gall. Ziekte was een gevolg van verstoring van het evenwicht tussen deze vier vloeistoffen of humora.

Galemus, die vanaf 164 n.Chr. in Rome de geneeskunst uitoefende was ook een aanhanger van deze humorale pathologie. Hij legde daarnaast nadruk op de betekenis van de anatomie. Het verrichten van lijkopeningen was echter verboden zodat anatomisch onderzoek van ziekte niet plaatsvond en de anatomie aan dieren moest worden bestudeerd. Voorts is Galenus te beschouwen als de grondlegger van de experimentele fysiologie: hij toonde aan dat in slagaderen bloed stroomt en dat het hart deze stroom in beweging zet. In de vroege Christelijke geneeskunst lag de nadruk niet op het onderzoek van ziekte, welke beschouwd werd als straf op zonde, maar op ziekenzorg en verpleging, met als leidraad voor de diagnostiek de door de Grieken ontwikkelde principes. In de Middeleeuwen lag het centrum van ontwikkeling van de geneeskunst in Arabie, waar de kennis van geneesmiddelen aanzienlijk werd uitgebreid en met de ontwikkeling van scheikunde ook een grondslag werd gelegd voor geneesmiddelenbereiding. Pas in de Renaissance gaat Europa weer een hoofdrol spelen in de ontwikkeling van de geneeskunst. Vooral anatomie maakt dan een enorme bloei door die resulisert in thet anatomisch standaardwerk van Andreas Vesalius van Padua. De ontwikkeling van het inzicht in de fysiologie resulteert in de herkenning van de bloedcirculatie door William Harvey. Opmerkelijk is echter dat het oude concept van de humorale pathologie blift bestaan. Als alternatief formuleert John Brown in de 18 e eeuw de gedachte dat er slechts twee typen ziekten bestaan, nl. sthenische en asthenische, die dan ook met respectievelijk sedativa en stimulantia dienen te worden behandeld. Van een op feiten gebaseerd inzicht in oorzaak en ontstaanswijze van ziekte is echter dan nog steeds geen sprake. Daarvoor wordt de grondslag gelegd door zorgvuldige klinische observatie zoals door Boerhaave, lijkopemingen en de correlatie van de bevindingen daarvan aan de klinische bevindingen zoals door Morgagni in de $18 \mathrm{e}$ en Von Rokitansky in de $19 \mathrm{e}$ eeuw. Opvallend is dat in de publicaties van Von Rokitansky nog steeds 
elementen uit de humorale pathologie voorkomen. Onbewijsbare vooronderstellingen behoren pas lat het verleden met het werk van Virchow, die dan ook als grondlegger van de moderne pathologie kan worden beschouwd.

Strikt wetenschappelijk gelundeerde pathologie kon zich ontwikkelen in de wisselwerking tussen het zorgvuldig klinisch waamemen enerzijds en de snel toenemende kennis van de humane anatomie en fysiologie anderzijds. Pathologische anatomie als klinisch specialisme bestond daamee echter nog niet: pathologie werd vooral bedreven door "geneesheren en heelmeesters" en omvatte in korte tijd niet alleen maar macroscopisch en microscopisch onderzoek wan weefsels doch ook microbiologisch en chemisch onderzoek van lichaamsvloeistoffen. De nadruk lag daarbij op het onderzoek van ziekteverwekkende, door ziekte veroorzaakte of met ziekte samenhangende verschijnselen en de relatie daarvan tot de diagnostiek, behandeling en preventie van en bescherming tegen ziekle. Pathologie was geen door de keuze van technieken of vraagstellingen afgebakend terrein van onderzoek, maar een wijze van benaderen van het verschijnsel ziekte, die van doorslaggevende betekenis bleek voor de verdere ontwikkeling van de geneeskunde.

Ten opzichte van de situatie in de tweede helft van de 19 e eeuw hebben zich in de pathologie een aantal belangrijke veranderingen voltrokken. Te noemen valt in de eerste plaats de ontwikkeling van de pathologische anatomie tot een zelfstandig klinisch specialisme, waarmee pathologisch-anatomisch onderzoek niet meer tot het werkterrein van "geneesheren en heelmeesters" ging behoren. Pathologie als benaderingswijze heeft echter zijn universaliteit behouden en kenmerkt ook het wetenschappelijk werk van vele andere medische specialisten. Het is overigens merkwaardig dat het medisch specialisme dat de morfologische pathologie als werkterrein heeft ziektekundige ontleedkunde of pathologische anatomie genoemd wordt. Omdat het brandpunt van de belangstelling niet de ontleedkunde maar juist de ziektekunde is, zou het beter zijn geweest te spreken van ontleedkundige ziektekunde of anatomische pathologie. Het specialisme word in de Verenigde Staten dan ook mijns inziens terecht. Anatomical Pathology" genoemid. In de tweede plaats hebben zich naast de pathologische anatomie een aantal deelgebieden ontwikkelid, die inmiddels grotendeels als zelfstandig specialisme zijn erkend, zoals medische microbiologie, klinische chemie, klimische 8 immunologie en experimentele pathologie. In landen zoals de 
Verenigde Staten heeft deze ontwikkeling niet geleid tot afsplitsing van afzonderlijke specialismen: daar wordt het merendeel der pathologen nog steeds opgeleid tot ,all-round" specialist, die zowel van de morfologische pathologie als van de medische microbiologie, klinische chemie en immunologie kennis heeft. Ook in Nederland is een tendens tot gedeeltelijke reintegratie van de pathologische anatomie met bijvoorbeeld onderdelen van de klinische immunologie te bespeuren. In de derde plaats heeft zich, parallel aan de uitbreiding van het arsenaal aan onderzoekstechnieken, een enorme verdieping van kennis voorgedaan. Virchow sprak van cellulaire pathologie. Met de introductie van het electronen-microscoop kon subcellulaire pathologie worden ontwikkeld en met de explosieve vooruitgang van de moleculaire biologie wordt nu moleculaire pathologie bereikbaar. Daartoe is de anatomische benadering van pathologie alleen echter niet meer toereikend en is inbreng van cel-en moleculaire biologie essentieel. Dat betekent ook dat pathologisch onderzoek niet meer alleen door artsen, al dan niet patholooganatoom, wordt verricht maar voor een belangrijk deel door daarvoor speciaal opgeleide onderzoekers. Tenslotte heeft de taak van de patholoog-anatoom zich veel meer toegespitst op de beoordeling van proefexcisie- en operatiemateriaal waarvan de resultaten direct van betekenis zijn voor de diagnostiek en de therapie van individuele patienten.

Als ik de willekeurige persoon was geweest die had moeten antwoorden op de vraag: "wat is pathologie?", zou min reactie vermoedelijk als volgt hebben geluid:

1. Pathologie past alle beschikbare technieken - morfologische, fysische, chemische, statistische en eventueel zelfs sociologische en psychologische-toe om de aorzaak en ontstaanswijze van ziekte op te helderen, omdat alleen langs die weg rationele diagnostiek, behandeling en preventie mogelijk is. Zlektekundig anderzoek is niet een doel in zichzelf maar een middel ter verbetering van de diagnostiek en behandeling van ziekte bij de individuele patient. In dit opzicht is een patholoog evenveel geneesheer als wetenschappelijk onderzoeker.

2. Pathologen zijn in de eerste plaats geinteresseerd in morfologische veranderingen van organismen, organen. weefsels en cellen. Pathologen gebruiken aanvullend 
ultrastructureel, immunologisch, celbiologisch en biochemisch onderzoek om het inzicht in de biologische betekenis van morfologische veranderingen te verdiepen. Pathologen Irachten Klinische verschijnselen uit de resultaten van dergelijk onderzoek te verklaren.

3. Pathologie is één ondeelbare discipline. Anatomische en experimentele pathologie zijn onlosmakelijk met elkaar verbonden. Specialisalie binnen de pathologie is echter noodzakelikk geworden door de explosieve toename van kennis. Naast het onderscheid in anatomische en experimentele pathologie komt dat ook tot uitdrukking in specialisatie naar orgaan (neuropathologie, gynaecopathologie), systeem (endocriene pathologie) of ziekte oorzaak (immunopathologie). Feiteligke fragmentatie, in de vorm van gescheiden laboratoria of binnen één laboratorium gescheiden groepen, is echter ongewenst.

4. Pathologie verbindt geneeskunst en biomedische basiswetenschap. Daarin staat de relatie lussen klinische verschijnselen en anatomische, ultrastructurele of biochemische veranderingen centraal, of in de woorden van Popper (1): "What we really love most is the sythesis, the functional - structural correlation, often speculative, always exciting: the clinical-pathological conference where the story is true, if it "s good".

\section{Histologische diagnostiek: van kunst naar wetenschap}

Ik wil nu graag met $u$ een aantal ontwikkelingen in de pathologische anatomie, met name met betrekking tot de diagnostiek door weefselonderzoek (histopathologische diagnostiek), aan een nadere beschouwing onderwerpen. Weefseldiagnostiek maakt op niet-pathologen vaak de indruk zeer exact en strikt wetenschappelijk te zijn. In werkelijkheid is het beoordelen van een histologisch preparaat een vaardigheid waarin zowel kritische analyse als op ervaring gebaseerde indrukken een rol spelen. Lang niet alle kenmerken, op grond waarvan een diagnose wordt gesteld, kunnen in maat en getal worden uitgedrukl en evenmin worden alle kenmerken door elke patholooganatoom identiek gewaardeerd. Een der belangrijkste

10 ontwikkelingen in de pathologische anatomie is het onderzoek 
naar meer objectiveerbare en reproduceerbare beoordelingscriteria. Teneinde van die ontwikkeling een juist beeld te kunnen schetsen is het goed om nog eens terug te gaan in de geschiedenis van de pathologie.

De vroegste waamemingen over anatomische veranderingen als gevolg van ziekte werden gedaan tijdens lijkopeningen, die als eerste doel verruiming van anatomische kennis hadden. In de beschrijuing van die waarnemingen, zoals in het werk van Antonio Benivieni (1440-1502), werd dan ook slechts in beperkte mate getracht de ziekteverschijnselen in verband te brengen met gevonden afwikingen. Een van de eerste onderzoekers die systematisch ziekteverschijnselen trachtte te verklaren wit waargenomen anatomische veranderingen was Morgagni, die daarmee een uiterst belangrijke grondslag legde voor alle latere ontwikkelingen. Het arsenaal aan onderzoeklechnieken waarover de zlektekundig geinteresseerde de beschikking had was uiteraard beperkt. In feite waren tot de ontwikkeling van microscopen en voor microscopie geschikte weefselbewerkingstechnieken, het mes en het geoeferde oog de enige ter beschikking staande instrumenten. Het is tegen deze achtergrond opmerkelijk hoeveel belangrijke waarmemingen er in de eeuw tussen de publicatie in 1761 van Morgagni's "Do sedibus et causis morborum" en van Virchow's .Die Cellular pathologie in ihre Begründigung aut physiologische und pathologische Gewebelehre" in 1858 werden gedaan. Morgagni ontdekte dat de halfzijdige verlamming bij een beroerte veroorzaakt wordt door een bloeding in de contralaterale hersenhelft. Hij beschreef de vaatafwijkingen als gevolg van syphilis, levercirrhose, acute gele leveratrofie en de kenmerkende sekwentie van longveranderingen bij longontsteking. Von Rokitansky, die eigenhandig meer dan 30.000 secties verrichtte, ontdekte het voorkomen van bacteriën in bacteriële endocarditis, een ernstige ontsteking van de hartkleppen. Ook beschreef hij de kenmerkende longveranderingen bij emfyseem. Von Rokilansky had echter nog niet geheel de tot dan toe breed aangehangen humorale pathologie verlaten, waarvoor hij door Virchow ernstig werd bekritiseerd.

Het persisteren van elementen uit de humorale pathologie in Von Rokitansky's opvattingen illustreent dat, hoewel het besef groeide dat aan zlekten anatomische afwijkingen ten grondslag liggen, wit het waarnemen van die afwijkingen niet steeds ook oorzaak en ontstaanswijze van die afwijkingen duidelijk werd.

Daarvoor waren een dieper inzicht in de normale macroscopische en microscopische anatomie, de fysiologie en de microbiologie 
essentieel. Bovendien was vaak onderzoek met het blote oog alleen onvaldoende: van veel pathologische veranderingen bleek de aard pas uit microscopisch onderzoek. Overigens werd het belang van microscopisch onderzoek niet door iedereen ingezien. Martyn Paine, een amerikaans fysioloog, schreef in 1840: We think it may be safely affirmed that the microscope has not added a solitary fact of practical use to atone lor all the evils which it has afflicted" (2).

Hoewel dus kennis over orgaanafwijkingen bil ziekte door pathologisch-anatomisch onderzoek reeds in de $18 \mathrm{e}$ eeuw ontstond, brak het inzicht in oorzaak en ontstaanswijze van veel ziekten pas door met het pionierswerk van Virchow. Het klinischpathologisch onderzoek resulteerde in een pathologische of pathogenetische classificatie van ziekte. In deze classificatie staat de aard van het ziekteproces centraal. Men onderscheidt ondermeer ontstekingen, regressieve veranderingen en stofwisselingsstoornissen, traumata, circulatiestoormissen, aangeboren afwijkingen en gezwellen. Naast pathologische classificatie is echter ook etiologische classificatie denkbaar: indeling van ziekten naar hun oorzaak, althans woorzover deze bekend is. Voor het vaststellen van de etiologie van een ziekte is klinisch pathologisch onderzoek alleen vaak onvoldoende; experimenteel onderzoek is daarvoor meestal een onmisbare aanvulling. Dit wordt fraai geillustreerd door hel werk van Koch, die de tuberkelbacil identificeerde als verwekker van tuberculose Koch stelde dat louter het vóórkomen wan een micro-organisme in een afwijking onvoldoende bewijs is voor een oorzakelijk verband. Alleen als het micro-organisme in leder geval van de betreffende ziekte voorkwam, het micro-organisme geisoleerd en gekweekt kon worden, hel geïsoleerde micro-organisme bij een besmet proefdier eenzelfde zieklebeeld veroorzaakte en het microorganisme uit hel geinfecteerde proefdier weer kon worden geïsoleerd, was het oorzakelijk verband vastgestell. Etiologische classificatie wordt vooral gebruikt voor door infectieuze microorgenismen veroorzaakte ziekten. Ook woor andere ziekten zou etiologische classificatie de voorkeur verdienen maar ondanks intensief onderzoek is van veel ziekten de oorzaak nog geheel of ten dele onbekend: gezwelgroei is daar een trelfend voorbeeld van.

Ook na Virchow bleef ziektekundige ontleedkunde vooral ten dienste staan van ziektekundig onderzoek: lijkopeningen werden verricht ter verrijking van het inzicht in oorzaak en ontstaanswijze 12. van ziekten, door correlatie van steeds meer gedetailleerde 
mortologische waamemingen met klinische verschijnselen. Met de snelle ontwikkeling van de heekunde aan het eind van de 190 eeuw en begin 20e eeuw ontstond de mogelikheid pathologisch onderzoek te doen aan operatiepreparaten. Het onderzoek hiervan verschafte echter niet alleen de mogelikheid tot het verdiepen van ziektekundig inzicht doch kon ook dienen ter verificatie van de door de arts gestelde diagnose of ter vasistelling van eventueel in te stellen aanvullende behandeling. Bovendien werd, met de geleidelijke ontwikkeling van een heel scala aan technieken waarmee cellen of weefsel uit een pathologisch proces verkregen konden worden, pathologisch-anatomisch onderzoek in toenemende mate gebruik voor primair diagnostische doeleinden. De grondslag van de pathologische anatomie bleef de nauwkeurige waarneming van morfologische veranderingen en de correlalie daarvan met waargenomen ziekteverschijnselen. Wel nam het arsenaal aan technieken, dat de patholoog-anatoom ter beschikking stond bij het onderzoek, toe. De histologische technieken werbeterden steeds en de ontwikkeling van methoden voor hel meer of minder specifiek aantonen van allerlei substanties in cellen of weefsels maakte een gedetailleerdie anallyse van de samenstelling daarvan mogelijk.

Elektronenmicroscopie verschafte de mogelijkheid zelfs op subcellulair niveau ziekteprocessen te bestuderen.

Bij het beschrijven van pathologische veranderingen werd door de grondleggers van de pathologische anatomie lang niet altijd gebruik gemaakt van morfologische kenmerken waarvan de oorzaak en biologische betekenis bekend waren. Ook in hedendaags pathologisch-anatomisch onderzoek is dat vaak nog niet het geval, met name wanneer het "naar hun oorzaak en ontstaanswijze, ten dele nog onbegrepen ziektebeelden betreft, zoals gezwellen. Dat betekent dat bij de classificatie van gezwellen, maar bijwoorbeeld ook voor de herkenning van allerlei vormen van ontsteking, gebruik gemaakt word wan voor een deel naar hun betekenis onbegrepen verschijnselen. Een enkel voorbeeld ler illustratie. Bij sommige vormen van schildkliercarcinoom bestaat de tumor grotendeels uit kleine holten waarin de tumorepitheelcellen woekeren als kleine bloemkooltjes, het zogenaamde papillaire carcinoom. De oorzaak van deze groeiwijze, die niet in een normale schildklier voorkomt, is niet bekend. Het fenomeen is echter zo karakteristiek voor dit type schildkliercarcinoom, dat men uitzaaiingen van de tumor eraan kan herkennen. Hel praktische belang van deze bevinding is dat papillaire carcinomen van de schildklier zich anders blijken te 
gedragen en ook anders behandeld moeten worden dan schildkliercarcinomen die niet deze groeiwijze vertonen. Het begruik van dergelijke criteria brengt tenminste twee problemen met zich mee. In de eerste plaats zijn ze strikt beschrijvend, dat wil zeggen ze duiden een moffologisch kenmerk aan waarvan de biologische betekenis niet altijd begrepen is. Het onderkennen van een dergelijk criterium, hoe bruikbaar ook. draagt derhalve niet direct bij tot een beter begrip van het betreffende ziektebeeld. In de tweede plaals neigt een dergelik criterium tot subjectiviteit. Het eerder genoemde papillaire schildkliercarcinoom is daarvan een sprekend voorbeeld. Het bleek namelijk dat niet alleen de groeiwijze van deze tumoren zilch onderscheidt van andere typen schildkliercarcinoom, maar dat ook de individuele tumorcellen er anders uitzien. De celkernen van het tumorepitheel vertonen onder bepaalde omstandigheden een egale, fijnkorrelige verdeling van de kernsubstantie, waardoor een microscopisch beeld ontstaat dat aan matglas doet denken. De matglaskern lijkt dus bruikbaar als additioneel criterium voor de herkenning van het papillaire schildkliercarcinoom. Nu blijkt het matglasaspect een door de weefselbewerking geintroduceerd artefact te zijn dat niet onder alle omslandigheden optreedt. terwill het ook niet in alle papillaire schildkliercarcinomen kan worden waargenomen. Bovendien blikt dat er schildkliercarcinomen voorkomen die zich, voor wat betreft hun uitzaaingsgedrag en graad van kwaadaardigheid, voordoen als papillair carcinoom doch niet het papillaire groeipatroon maar wel matglaskernen vertonen. Hel gevolg is dat meermalen een schildkliercarcinoom als papillair wordt geclassificeerd, alleen op grond van hel voorkomen van matglaskernen. Er zijn echter geen algemeen aanvaarde afspraken over de objectiveerbare criteria waaraan een mogelijke matglaskern moet voldoen en evenmin over de vraag hoeveel matglaskemen noodzakelijk zijn voor een definitieve diagnose.

Hel verantwoord hanteren van dergelijke morfologische criteria is een kunst die een patholoog-anatoom met het toenemen van zijn ervaring in het vak steeds beter gaat beheersen. Het subjectieve element, en daarmee ook de niet altjd wlekkeloze reproduceerbaarheid van de diagnose, blift daarmee.

Het zal U duidelijk zijn dat vooral de patholoog-anatoom zelf met dergelijke beoordelingscriteria niet erg gelukkig is. Een belangrijk deel van het wetenschappelijk onderzoek door patholooganatomen is er dan ook op gericht in probleemgebieden 14 eenduidige en beter objectiveerbare criteria te ontwikkelem. 
Gelukkig staat daarvoor inmiddels een uitgebreid arsenaal aan technieken ter beschikking.

Ik heb in het voorbijgaan reeds melding gemaakt van het electronenmicroscoop, waarmee tal van pathologische celveranderingen zeer gedetailleerd in kaart zijn gebracht. Een andere ontwikkeling is het gebruik van instrumenten waamee microscopische veranderingen in weefsels en cellen gekwantificeerd kunnen worden. Met dergelijke zogenaamde morfometrische technieken is het mogelijk bestaande morfologische kenmerken in maal en getal uit te drukken en aidus te objectiveren. Ook kunnen met deze technieken nieuwe morfologische parameters worden ontwikkeld. Het zijn echter vooral de histochemische technieken die in de pathologischanatomische diagnostiek een explosieve ontwikkeling doormaken (3). Met histochemische technieken is het mogelijk door chemische kleurreacties globaal de samenstelling wan cel-en weefselcomponenten te analyseren (conventionele histochemische kleuringen), de hoeveelheid van bepaalde stoffen zoals nucleinezuren in cellen te meten (kwantitatieve histochemie), de enzyminhoud van cellen vast te stellen (enzymhistochemie) of, gebruik makend van de unieke interactie tussen een antistof en het bijpassend antigeen, een heel scala van celcomponenten specifiek aan te tonen (immunohistochemie). Met name de immunohistochemische technieken worden de laatste jaren in sterk toenemende mate in de histopathologische diagnostiek gebruikt omdat met deze technieken in principe iedere substantie, waartegen een specifieke antistof kan worden opgewekt, in weefsel is te localiseren $(4,5)$.

De gerichtheid van veel pathologisch anatomisch onderzoek op eenvoudiger en beter objectiveerbare diagnostische criteria maakt de vraagstelling bij dergelijk onderzoek vaak nogal beperkt. Een ultrastructureel geinteresseerd onderzoeker zou, om bil hetzelfde voorbeeld te blijven, de celorganellen in typisch papillaire en folliculaire (waarin de tumorcellen blaasjes of follikels vormen) schildkliercarcinomen met elkaar kumen vergeliken om vervolgens te bezien of de eventueel gevonden verschillen het mogelijk maken om in twijfelgevallen met meer zekerheid een der diagnosen te stellen of te verwerpen. De morfometrisch geinteresseerde zou kunnen onderzoeken of de gemiddelde kerngrootte, kerncontour en kernsubstantieverdeling in papilaire carcinomen anders is dan in folliculaire en zo ja, of deze criteria diagnostisch bruikbaar zijn. De kwantitatief histochemisch geinteresseerde zou kunnen onderzaeken of de hoeveelheid 
nucleinezuur per cekeri in een papillair carcinoom hoger of lager is dan in een folliculair carcinoom. De enzymhistochemisch geinteresseerde zou zich kunnen afwragen of er voor wat betreft de aanwezigheid van enzymen met peroxidase-activiteit verschil bestaat tussen papillair en folliculair carcinoom en de immunohistochemisch geinteresseerde tenslotte zou zich eenzelfde vraag kunnen stellen met betrekking tot de productie in de tumorcellen van thyreoglobuline, een voor transport en opslag van schildklierhormoon in de schildklier belangrijk ewit.

In deze opsomming die wellicht een wat gechargeerd en eenzijig beeld geeft van histopathologisch onderzoek maar niet zo erg ver bezijden de waarheid is, ligi de nadruk steeds op het vinden van nieuwe en wellicht meer betrouwbare klassificatiecriteria.

Dergelijk onderzoek richt zich miet primair op het verkrijgen van een beter inzicht in de bestudeerde zlekte en de resultaten ervan dragen daartoe vaak ook niet direct bij. Wel wordt de kunst van het herkennen steeds meer verfijnd. Dat is zowel voor de patholoog anatoom zelf als voor de andere klinische specialisten van groot belang: de beoordeling wordt betrouwbaarder en resulteert in diagnosen die informatief zijn met betrekking tot handelbaarheid en prognose van hel betreffende ziektebeeld. Er is evenwel ook een reëel risiko van overwaardering van deze "geavanceerde technieken" in de diagnostische histopathologie. In de eerste plaats geldt bijvoorbeeld met name voor immunohistochemie dat van lang niet alle in de literatuur beschreven toepassingen de betrouwbaarheid in overtuigend vergelikkend onderzoek is vastgesteld. Dat is ten dele een gevolg van de techniek zelf, die betrekkelijk gemakkelijk uitvoerbaar is maar desondanks toch niet geheel zonder voetangels en klemmen. Voor een ander deel is dat een gevolg van de snel voortgaande ontwikkeling van antistoffen tegen nieuwe, al dan niet geidentificeerde celbestanddelen, waarvan de specificiteit voor een bepaalde diagnose niet altijd afdoende is vastgesteld. In de tweede plaats dient men zich te realiseren dat de gegevens verkregen door toepassing van een geavanceerde techniek niet dezelfde betekenis hoeven te hebben als die waarop een strikt morfologische classificatie is gebaseerd. Ik kan dat het beste weer aan een voorbeeld toelichten.

Naast het eerder genoemde papillaire en folliculaire carcinoom van de schildklier komen nog tenminste twee andere typen voor, namelijk het medullaire carcinoom, dat ontstaat uit een ander celtype dan papillair en folliculair carcinoom en het 16 ongedifferentieerde carcinoorn. Dit laatste is het meest. 
kwaadaardige type en wordt zo genoemd omdat de tumorcellen niet meer lijken op de cellen die normaal in de schildklier voorkomen. Immunohistochemisch onderzoek heeft uitgewezen dat in een aanzienlijk deel van de ongedifferentieerde carcinomen een hormoon (calcitonine) voorkomt, dat ook door alle medullaire schildkliercarcinomen wordt geproduceerd en door de cellen in de schildklier (de zogenaamde parafolliculaire cellen) waar medullaire carinomen waarschijnlijk uit ontstaan (6). Het lag dus voor de hand om ongedifferentieerde carcinomen mel calcitonineproductie ook te beschouwen als medullair carcinoom. Nader onderzoek van het beloop van deze tumoren leerde echter dat deze, evenals de overige ongedifferentieerde carcinomen, een uiterst slechte prognose hebben, terwijl het klassieke medullaire carcinoom doorgaans een vrij goede prognose heeft. Het fenomeen calcitonineproductie identificeert dus niet een, wat hun gedrag betreft, homogene groep tumoren. Van dit verschijnsel zijn talrijke andere voorbeelden aan te halen.

Een derde reden, tenslotte, om een opmerking te maken over overwaardering van de ,geavanceerde technieken" is het verschijnsel dat onderzoek naar toepassing daarvan in de diagnostiek een onevenredig groot deel van de onderzoekinspanning van de universitaire pathologische laboratoria gaat innemen. Een pathologisch laboratorium, dat ook algemene pathologie tot haar vakgebied rekent, dient een belangrijk deel van het wetenschappelijk onderzoek te richten op vragen naar oorzaak en ontstaanswijze van zlekten. In het optimale geval zal fundamenteel onderzoek aan humaan materiaal of aan dierexperimentele modellen het inzicht in deze aspecten van de bestudeerde ziekte verdiepen, terwijl de ontwikkelde technieken toepassing zullen vinden in de histologische diagnostiek. Op deze wijze komt de organische samenhang tussen experimentele pathologie en pathologische analomie volledig tot zijn recht.

\section{Medisch basisonderwijs: meer kunst of meer wetenschap?}

Het derde en laatste punt dat ik met $U$ wit bespreken betreft het universitair medisch onderwijs. I $k$ wil dit deel van mijn betoog richten op de wraag, die nogal eens in discussies rond inhoud en vormgeving van de medische basisopleiding gesteld wordt, of in die opleiding de praktijk van de geneeskunst of juist de wetenschappelijke grondslag centraal moet staan. Een medisch 
student betoogde onlangs dat het ,protiel van de huisarts nieuwe stijl" er als volgt zou moeten uitzien: ,een kruising van de huidige huisarts met een maatschappelik werker en toegewijd om hulp te verlenen, zonder het universitaire aureool van grensverleggende wetenschappelike arbeld" (7). Deze stelling wordt onderbouwd vanuit twee uitgangspunten. Het eerste is dat van de klachten waarmee de patienten zich tol artsen wenden $80 \%$ geen oorzaak heeft in , lichamelijk" lijden. In de opleiding ligt echter de nadruk op het herkennen van (lichamelike) symptomen, het stellen van diagnosen en het behandelen van de gevonden (lichamelike) aandoening. Er wordt dus vastgesteld dat de opleiding niet aansluit aan de dagelijkse praktijk. Het tweede uitgangspunt is dat in onze cultuur ziekte te weinig als aan leven inherent verschijnsel wordt gezlen en dat, vooral uit de enorme stijging van de kosten van de gezondheidszorg zonder noemenswaardige verlenging van de gemiddelde leeftijd, de conclusie gewettigd lijkt dat gezondheid niet te koop is.

Deze laatste stelling likt me op grond van een groot aantal argumenten, waarop ik hier niet nader wil ingaan, nogal aanvechtbaar. De opvatting dat het medisch basisonderwijs en de praktijk van de geneeskunde niet goed op elkaar aansluiten komt echter zo vaak voor dat er een element van waarheid in moet zitten. Voor de kennelijk ontstane divergentie zijn in principe twee verklaringen mogelijk. De eerste is dat de wetenschappelijke uitgangspunten, zoals die in het thuidige universitaire medisch onderwijs worden gehanteerd, de praktizerende arts niet goed woorbereiden op de herkenning en behandeling van de gezondheidsproblemen waarmee deze wordt geconfronteerd. De andere is dat in de praktijk onvoldoende of onjuist gebruik wordt gemaakt van die uitgangspunten en dat daardoor aard en oorzaak van veel gezondheidsproblemen niet goed worden onderkend. Populair gezegd komt dit neer op: de theorie is wel mooi maar is in de praktijk onbrukbaar of de theorie wordt onvolledig of onjuist gebruikt en lijkt daardoor onbruikbaar.

Als men van de eerste verklaring uitgaat lijkt de oplossing van het probleem van divergentie tussen opleiding en praktijk betrekkelijk eenvoudig, althans inhoudelik. De wetenschappelijke basisopleiding zou dan in belangrijke mate kunnen worden gereduceerd. Studenten wier belangstelling primair uitgaat naar de biomedische wetenschappen zouden een strikt wetenschappelijke opleiding kunnen volgen, die aansluit op een loopbaan in het biomedisch onderzoek. In dit kader zou de instelling van een studierichting biologische ziektekunde, als tegenhanger van 
biologische gezondheidkunde overwogen kunnen worden. Voor toekomstige artsen zou de wetenschappelike basisopleiding echter in belangrijke mate kunnen worden gereduceerd. Vroeg in de opleiding zou een student moeten kiezen voor het terrein van de gezondheidszorg waarin hij of zij werkzaam wil zijn. Vervolgens wordt de student gedurende de opleiding met een uitgebreid scala van voor dat terrein relevante praktijkproblemen geconfronteerd en oefent zich in het aandragen wan oplossingen, zonder zich daarbij al te veel te bekommeren om de vraag naar de diepere oorzaak van die problemen. Deze oplossing zou aardig aansluiten bij de eerder gegeven scheis van de "huisarts nieuwe stijl". Hiermee zou dan wel de opleiding tot arts gereduceerd worden tot hoger beroepsonderwijs.

Is dat gewenst? Mijns inziens past hier slechts een hartgrondig "nee". Daarbij is het echter goed te beseffen dat aan de Nederlandse Universiteiten de wetenschappelijke basis van de studie in de geneeskunde bedenkelijk small dreigt te worden. Aan de "conventionele" faculteiten is dat mede een gevolg van de nadruk op het verwerven van veel feitenkennis, waarvan het niveau wordt getoelst in gefragmenteerde meerkeuze-vraag tentamens, hetgeen de kans op de inductie van, ,tentamenstudenten" sterk verhoogt. Maar ook het Maastrichtse onderwijssysteem, dat de student de vrijheid biedt in belangrijke mate zelf te bepalen wat in de opleiding belangrijk is en wat niet. draagt de mogelijkheid van een ciergelijke ontwikkeling in zich. Het is onmiskenbaar dat de keuze van studenten vaak meer in de richting van de geneeskundige praktijk gaat dan in de richting van de biomedische basisvakken. Hiervan is ook de zeer beperkte belangstelling voor een wetenschapsstage een illustratie.

Voor de beantwoording van de vraag welke kant het op moet met het medisch onderwijs is het belangrijk nog eens op te sommen wat van een basisarts mag worden verwacht. Voor wat betreft de medische faculteit van deze universiteit is daarvan een recent overzicht gegeven in het "Spiderman" rapport (8). In de daar gegeven omschrijving wordt de nadruk gelegd op basiskennis (van humane biologie, pathofysiologie, somatische diagnostiek en therapie, psychalogie en psychopathologie), goed on (wikkelde vaardigheden (lichamelijk onderzoek, gesprekstechniek, probleemoplossing) en instelling (wetenschappelijk, zelfevaluerend). Ook worden enkele karaktertrekken genoemd (humaniteit, mensenkennis). Het is opmerkelijk dat in het rapport de term, "kritisch-wetenschappelijk" herhaaldelijk wordt gehanteerd maar dat wetenschappelijk onderzoek niet voorkomt in 
de opsomming van toekomstige taken, waarvoor de basisarls moet zijn toegerust. Een lets bescheidener visie geeft Tosteson, decaan van Harvard Medical School in een vrij recenl assay onder de litel "Leaming in Medicine" (9). Hij omschrijpt hel doel van de medische opleiding als, to prepare persons to learn in medicine", leren uit eigen ervaringen in de uitoefening van de geneeskunst.

Daartoe dient de arts le beschikken over basisconcepten met betrekking tot de mens als levend organisme (biomedische wetenschappen) en de mens als individu (menswetenschappen). Hel probleem is nu dat op elk van deze terreinen de hoeveelheid beschikbare informatie zo groot is en met een zodanig tempo groeit dat het toenemend moeilijk wordt te bepalen wat en op welke wijze in het curriculum moet worden ondergebracht. Teveel detailkennis overspoelt de student en wordt niet operationeel, een verschijnsel dat in de conventionele medische opleidingen duidelijk kan worden waargenomen. De door Tosteson aangedragen oplossing heeft veel weg van de uitgangspunten van het onderwijs aan de Maastrichtse faculteit. Elke student dient zich een globaal inzicht te werwerven in de essentiële natuurwetenschappelijke, sociaal wetenschappelijke en mensenwetenschappelijke grondslagen van de geneeskunde. De invulling van globale inzichten met detailkennis kan aan de belangstelling van de individuele student worden overgelaten. Cruciaal is in de opvatting wan Tosteson echter, en ik vermoed dat dat ook bedoeld is met de omschrijuing , kritischwetenschappelijke instelling" in het Spiderman-rapport, "the need for more emphasis on technics of learning and decision making, on quantitative methods and information management". De conclusie moel dus zijn dat wetenschappelijke vorming, niet zozeer door het consumeren van wetenschappelijk feitenmateriaal maar door het zich eigen maken van een wetenschappelijke benadering, een onmisbaar deel dient te vormen van de medische basisopleiding. Daarmee zijn we terecht gekomen bij de tweede mogelijke verklaring van de divergentie tussen opleiding en praktijk: onvolledig of onjuist hanteren van de theoretische grondslagen. Vóó het zich eigen maken van een wetenschappelijke benadering tijdens de medische basisopleiding zijn twee belangrijke argumenten. Het eerste betreft de voortgaande zelfevaluatie of, anders gezegd, het bil voortduring leren uit eigen ervaring van de praktizerende medicus. Zinvol evalueren en daaruit lering trekken kan alleen als het daarvoor noodzakelijke methodologische instrumentarium ter beschikking 
staat. In dit kader kan men denken aan kritische literatuurstudie. wetenschappelijke rapportage, statistiek, epidemiologie, besliskunde, methoden van gegevensverwerwing en gegevensverwerking. Het tweede betreft de vooruitgang in de medische wetenschap. Het verrichten van wetenschappelijk onderzoek in de geneeskunde dient niet voorbehouden te zi hn aan daartoe exclusief opgeleide specialisten. De arts onderzoeker behoort in de medische wetenschap een centrale rol te spelen. Een keur van argumenten wordt daarvoor aangedragen door Wyngaarden die signaleert dat er sprake is van, ,The clinical investigator as an endangered species" (10). Hij stelt dat de arts. onderzoeker een zeer bijzondere rol speelt door hel aandragen van voor de geneeskunde relevante vraagstellingen, door het toepassen van nieuw verworven basiskennis bij het onderzoek van ziekte en door het inbrengen van die kennis in hel onderwijs. Op welke wijze kan bereikt worden dat het eindproduct van de medische opleiding degelijk wetenschappelijk is onderlegd? In de eerste plaats dient in het curriculum, zowel in de omschrijving van de inhoud als in de praktische uitvoering, dat wetenschappelijk karakter duidelijk naar voren te komen. Het is verheugend dat deze medische faculteit, de noodzaak daartoe onderkennende. een commissie heeft ingesteld ter, verwetenschappelijking van het curriculum". Mijns inziens is een verplichte wetenschapsstage van voldoende duur om de student de gelegenheid te geven tot het zelfstandig verrichten van wetenschapelijk onderzoek, van die verwetenschappelijking een essentieel onderdeel. Een ander essentieel onderdeel is de vaststelling van de inhoud van het basis curriculum. Het dient duidelijk te zijn over welke operationele kennis en vaardigheden een arts dient te beschikken om kritisch wetenschappelijk te kunnen functioneren. Mijns inziens behoort ziektekunde, kennis van en inzicht in de oorzaken en ontstaanswijzen van ziekte, in dat basis curriculum een centrale rol te spelen en ik hoop deze visie gestalte te geven in mijn onderwilsactiviteiten.

De tweede factor die bepalend is voor de kwalitelt van hel eindproduct van de medische opleiding is gelegen in de selectie van tot die opleiding toe te laten studenten. Als, en nu stel ik het wat extreem, tot de opleiding bij voorkeur niet wetenschappelijk geinteresseerde studenten worden toegelaten zal de opleiding. hoe wetenschappelijk ook van opzet, niet resulteren in wetenschappelijk goed onderlegde artsen. Inhoud en opzet van de opleiding zijn niet de enige en misschien zelfs niet de belangrijkste bepalende factoren; aanleg en belangstelling van de 
student zin dat evenzeer. In dit opzicht is loting een onbrukbaar selectiemiddel. I $k$ ben me ervan bewust dat het vinden van een alternatief, dat zowel effectief als praktisch haabaar is, niet eenvoudig zal zijn maar als het verbeteren van het eindproduct van de medische opleiding de beleidsbepalers ernst is, zal ook daaraan aandacht moeten worden besteed.

Is de dokter dan alleen onderzoeker en de patient onderzoeksobject? Allerminst. "Zonder een figuur als de huisdokter kan een gezin in een ontwikkelde samenleving niet bestaan". zegt dr. Oreshchenkov tegen Ludmilla Afanasyevna in Solzjenitsyn's Kanker-paviljoen. ,Hij kent de noden van elk gezinslid, zoals de moeder hun smaak kent. Er steekt niets beschamends in naar hem toe te gaan met de een of andere onbeduidende klacht, waarmee je nooit naar de polikliniek zou zijn gelopen, omdat je dan weer een patientenkaart had moeten halen en op je beurt wachten, terwijl er bovendien negen patienten per uur worden afgewerkt. Toch komen uit zulke onbeduidende klachten alle verwaarloosde kwalen voort. Hoeveel volwassenen lopen nu, op dit ogenblik, niet in stomme paniek rond, verlangend naar een dokter, bil wie ze al de angst kumnen uitstorten, die ze in het verleden hebben weggestopt, waarvoor ze zich zelfs soms schamen? Het vinden van de geschikte dokter is lets, waarbij je niet altijd de raad van je vrienden kunt inroepen. Een advertentie in de krant zetten gaat ook niet. Eigenlijk is het een even intieme kwestie als het kiezen van een echtgenoot of een vrouw. Maar tegenwoordig kom je makkelijker aan een wrouw dan aan een dokter, die bereid is, je, zolang je dat wenst zijn persoonlijke aandacht te geven en die je werkelijk volkomen begrijpt" (11).

Aan het einde van deze rede gekomen betuig ik graag mijn dank aan hel College van Bestuur voor het in mij gestelde vertrouwen, dat resulteerde in de woordracht voor mijn benoeming tot hoogleraar in de pathologie aan de Rijksuniversiteit Limburg. Ik beschouw het als een voorrecht een ral te mogen spelen bij de verdere opbouw van Nederlands jongste universiteit.

Het doet mij veel genoegen dat mijn ouders deze plechtigheid kunnen bijwonen. I $k$ ben $U$ beide veel dank verschuldigd voor wat $U$ zichzell ontzegde om mijn worming te bekostigen, voor de levenshouding die ik meekreeg en voor Uw nog steeds actieve belangstelling voor datgene wat mij drift en bezig houdt. 
Dames en Heren, leden wan de wetenschappelike staf wan dewe universiteit,

dat ik samen met $U$ mag werken aan de realisatie van het doel waarvoor de Rijksuniversiteit Limburg zich gesteld ziet:

vernieuwing van het onderwijs, en met betrekking tot de Faculteit der Geneeskunde, de opleiding van een voor zinn of haar taak optimaial toegeruste basisarts, beschouw ik als een eervolle uitdaging. Ik heb getracht $U$ een beeld te schetsen van mijn uitgangspunten; ik hoop daarvan uitgaande een zinvolle bildrage te kunnen leveren.

Hooggeleerde van Rijssel, Hooggeleerde Schaberg, beste Theo en Aart,

te zijn ingeleid in de algemene ziektekunde en opgeleid tot patholoog anatoom in hel Leidse laboratorium, dat onder jullie leiding een uiterst belangrijke rol heeft gespeeld bij de ontwikkeling van de pathologie in Nederland, beschouw ik als een groot voorrecht. Ik hoop een stuk van de Leidse traditie in Maastricht te kunnen voortzetten.

Hooggeleerde van Duijn, Hooggeleerde van der Ploeg, beste Piet en Mels,

mede onder jullie leiding heeft een zeer belangrijk deel van mijn vorming tot wetenschappelijk onderzoeker plaatsgevonden. Van jullie wijze lessen profiteer ik nog dagelijks. Ik verwacht dat de werkkontakten die we tot nu toe hebben kunnen onderhouden, zullen blijven bloeien. De bestaande vriendschapsbanden zijn daar een betrouwbare garantie voor.

Hooggeleerde Swaen, beste Victor, amici stafleden van de capaciteingroep Pathologie,

in de maanden die verstreken zijn sedert mijn komst naar Maastricht, zijn mijn hooggespannen verwachtingen niet telleurgesteld. Dat mijn start hier voorspoedig is verlopen is mede te danken aan het enthousiasme en de openheid waarmee ik in jullie midden ben opgenomen. Ik zie de ontwikkeling van de Pathologie in Maastricht met vertrouwen tegemoet. 
Dames en Heren studenten,

ik hoop $U$ in deze bespiegelingen duidelijk gemaakt te hebben hoe belangrijk inzicht in oorzaak en ontstaanswijze van ziekten is voor een optimale beroepsuitoefening van etke arts. De logische consequentie van die overtuiging is dat in de laakstelling van de capaciteitsgroep Pathologie het onderwijs een hoge prioriteit heeft. Ik hoop dat wij elkaar in dit opzicht niet teleur zullen stellen.

Heren collegae patholoog-anatomen wit de regio,

Deze faculteit heeft regionale samenwerking hoog in haar vaandel staan. Het ligt in mijn bedoeling de regio niet in dat vaandel te laten, maar samen met $U$ gesitalte te geven aan onze gemeenschappelijke taak in de gezondheidszorg in Zuid-Limburg.

Ik heb gezegd. 


\section{Literatuur}

1. H. Popper. A concept of pathology. Human pathology 7 (1976). 609.

2. M. Paine. Geciteerd naar L. Orci. Macro and microdomains in endocrine pancreas. Diabetes 31 (1982) 538

3. P.J. Stoward en J.M. Polak (Red). Histochemistry. The widening horizons of its applications in the biomedical sciences. J. Wiley \& Sons, Chichester, 1982.

4. F.T. Bosman en A.C. Nieliwenhuyzen Kruseman. Clinical application of the enzyme-labeled antibody method. Immunoperoxidase methods in diagnostic histopathology. J. Histochem. Cytochem. 27 (1979), 1140.

5. K. Mukai \& J. Rosai. Applications of immunoperoxidase techniques in surgical pathology. Progress in Surgical Pathology, val. 1 (C.M. Fenoglio en M. Wolff, Red.), Masson, New York, 1981.

6. A.C. Nieuwenhuyzen Kruseman, F.T. Bosman e.a. Medullary differentiation of anaplastic thyroid carcinoma. Am.J. Clin.Pathol. 77 (1982), 541.

7. R. Dekkers. Gezondheid. NCR-handelsblad, 15 december 1982.

8. Commissie Spiderman, De Spiderman, R.U.L., 1982.

9. D.C. Tostesan, Learning in medicine, New Engl. J. Med. 301 (1979), 690.

10. J.B. Wyngaarden. The clinical investigator as an endangered species New Engl. J. Med. 301 (1979), 1254.

11. A. Solzjenitsyn. Kankerpaviljoen II. De boekerij, Baarn, 1968. p. 129 . 